\title{
Development of correlation-regression model between land use change and water quality indices in Ciliwung watershed
}

\author{
Yopy $\operatorname{Arfan}^{1, *}$, Dwita Sutjiningsih ${ }^{1}$ \\ ${ }^{1}$ Department of Civil Engineering, Faculty of Engineering, Universitas Indonesia, Depok 16424, Indonesia
}

\begin{abstract}
Urbanization and industrialization lead to the change of land cover from pervious into impervious. This can impact environmental problems such as water quality degradation that affects human health and water ecosystems. The study aimed to develop a regression-correlation model between impervious cover in Ciliwung watershed and water quality indices in Ciliwung river. The correlation-regression model can be used to predict changes in the status of Ciliwung river water quality due to impervious cover changes. Methods of assessing the indices of water quality are CCME-WQI, NSF-WQI, and STORET within the period of 20052016. Monitoring locations from the most upstream to downstream are Atta'awun, Katulampa, Kedung Halang, Pondok Rajeg, Panus Bridge, Kelapa Dua, Condet, Kalibata, MT Haryono and Manggarai. Impervious cover data for each water quality monitoring location is processed using ArcGIS Software. Test of correlation significance between percentage of impervious cover and water quality indices using Pearson Correlation test method. The result of correlation test is significantly a strong inverse relationship between impervious cover and water quality indices. The result of regression test is trend line between impervious cover change and water quality indices that can be used to predict the change of water quality status in Ciliwung River.
\end{abstract}

\section{Introduction}

The development of urbanization and industrialization resulted in increased the land cover from pervious to impervious. During 2000-2010 there was an increase of $20 \%$ settlement land in Ciliwung watershed [1]. The rapid change of land into commercial building, residential, and agricultural areas that are not properly managed will produce waste water that impact on the decrease of river water quality. The increasing impervious cover resulted in environmental problems such as water quality degradation that affected human health and water ecosystem [2]. The impermeable surface precludes the infiltration of rainwater into the soil and ground water, which cause increased surface runoff water to the river, then leads to changes in water quality $[3,4]$.

Impervious cover (IC) is one of the important factors that affect the water quality status [5, 6]. Impervious cover model at first was developed by Schueler (1994), that aim to find out how the impact of impervious cover toward various water quality and biotic indicators. The Impervious cover model (ICM) defines four categories of urban streams based on how much IC exists in their contributing subwatershed, namely : sensitive, impacted, nonsupporting, and urban drainage [5]. Impervious cover model can be used to predict stream quality. Impervious cover model (ICM) was later modified by Schueler et al. (2009). This modification prevents the misperception that streams with low subwatershed IC will automatically possess good or excellent quality [5].

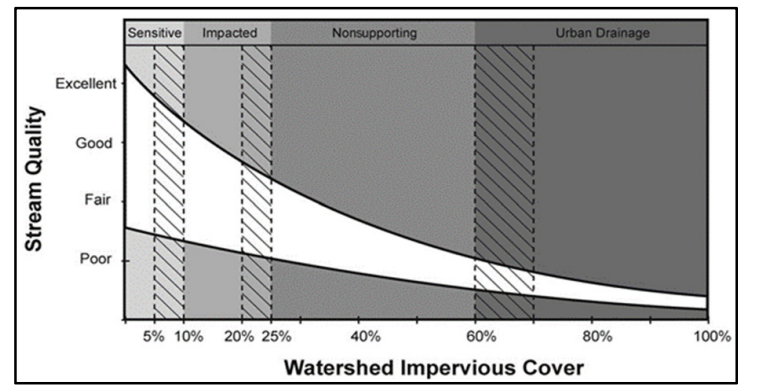

Fig. 1. Modified Impervious cover model [5].

Determination of river water quality status is very important to know the condition of river pollution level. Water Quality Index (WQI) is a method of simplification of the number of water quality parameters data into a number that can describe the status of water quality so that it can be understood by the public in general. There are various methods of Water Quality Index (WQI) such as The CCME-WQI Method [7], STORET method [8], NSFWQI method [9], and other methods.

The study aimed to develop a correlation-regression model between impervious cover in Ciliwung watershed and water quality indices in Ciliwung river. Determination of Ciliwung river water quality status using CCME-WQI, NSF-WQI and STORET method. The correlation-regression model can be used to predict the water quality status in Ciliwung river due to the changes of impervious cover.

\footnotetext{
* Corresponding author: arfan.yopi@gmail.com
} 


\section{Research Methodology}

\subsection{Study Location}

The study was conducted in Ciliwung watershed starting from the upper ciliwung in Pangrango and Gede Mountain flowing northward through Bogor, Depok, and Jakarta up to Manggarai. Ciliwung river located in West Java and DKI Jakarta Province. The area of Ciliwung watershed up to Manggarai is approximately $\pm 344.2 \mathrm{~km}^{2}$ and the main river length approximately $\pm 114 \mathrm{~km}$.

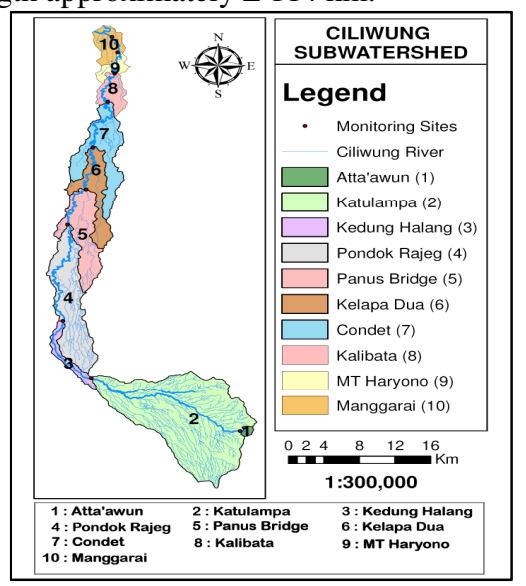

Fig. 2. Map of Ciliwung Watershed.

Table 1. Water Quality Monitoring Locations

\begin{tabular}{|c|c|c|c|c|}
\hline \multirow{2}{*}{ No } & \multirow{2}{*}{$\begin{array}{l}\text { Monitoring } \\
\text { Locations }\end{array}$} & \multicolumn{2}{|c|}{ Coordinates } & \multirow{2}{*}{$\begin{array}{c}\text { Total Area } \\
\left(\mathbf{k m}^{2}\right)^{*}\end{array}$} \\
\hline & & South Lat. & East Long. & \\
\hline 1 & Atta'awun & $06^{\circ} 41^{\prime} 56.2^{\prime \prime}$ & $106^{\circ} 59^{\prime} 14.5^{\prime \prime}$ & 1.42 \\
\hline 2 & Katulampa & $06^{\circ} 37^{\prime} 59.7^{\prime \prime}$ & $06^{\circ} 50^{\prime} 12.6^{\prime \prime}$ & 150.75 \\
\hline 3 & Kedung Halang & $06^{\circ} 33^{\prime} 45.4^{\prime \prime}$ & $106^{\circ} 48^{\prime} 29.5^{\prime \prime}$ & 159.70 \\
\hline 4 & Pondok Rajeg & $06^{\circ} 26^{\prime} 43.7^{\prime \prime}$ & $106^{\circ} 48^{\prime} 46.2^{\prime \prime}$ & 214.75 \\
\hline 5 & Panus Bridge & $06^{\circ} 24^{\prime} 02.4^{\prime \prime}$ & $106^{\circ} 49^{\prime} 54.3^{\prime \prime}$ & 250.11 \\
\hline 6 & Kelapa Dua & $06^{\circ} 20^{\prime} 56.2^{\prime \prime}$ & $106^{\circ} 50^{\prime} 18.2^{\prime \prime}$ & 275.32 \\
\hline 7 & Condet & $06^{\circ} 17^{\prime} 34.2^{\prime \prime}$ & $106^{\circ} 51^{\prime} 12.5^{\prime \prime}$ & 312.78 \\
\hline 8 & Kalibata & $06^{\circ} 15^{\prime} 28.5^{\prime \prime}$ & $106^{\circ} 51^{\prime} 37.7^{\prime \prime}$ & 324.91 \\
\hline 9 & MT Haryono & $06^{\circ} 13^{\prime} 53.5^{\prime \prime}$ & $106^{\circ} 51^{\prime} 48.6^{\prime \prime}$ & 331.35 \\
\hline 10 & Manggarai & $06^{\circ} 15^{\prime} 28.5^{\prime \prime}$ & 10651'37.7”| & 344.20 \\
\hline
\end{tabular}

* Total Area up to monitoring location of ciliwung river

\subsection{Framework of The Study}

This study was conducted with several stages, namely data collection, land use data processing, determine water quality indices, and correlation-regression analysis.

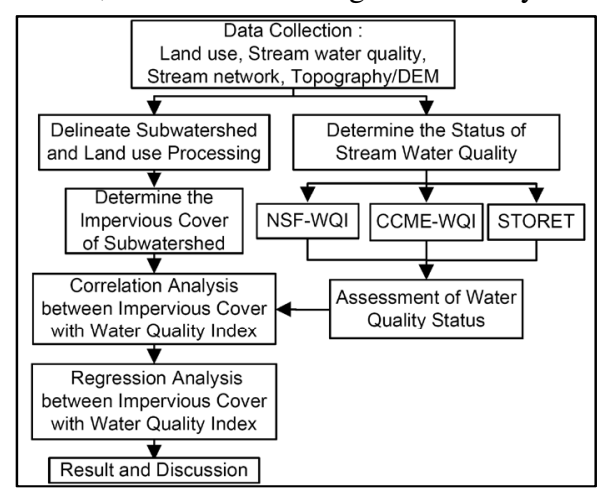

Fig. 3. Flow Diagram of The Study.

\subsection{Water Quality Indices Methods}

\section{CCME-WQI Method}

CCME-WQI method is the calculation to determine the status of the water quality by combining three vectors $\left(\mathrm{F}_{1}\right.$ Scope, $\mathrm{F}_{2}$ Frequency and $\mathrm{F}_{3}$ Amplitude). Water quality parameters assessed include $\mathrm{DO}, \mathrm{BOD}, \mathrm{pH}$, temperature, Turbidity, TSS, Nitrate, Total phosphate, and Fecal Coliform in the period of 2005-2016. Calculation of CCME-WQI method using the following equation [7]:

$$
\begin{aligned}
& F_{1}=\left(\frac{\text { Number of failed paramters }}{\text { Total number of parameters }}\right) \times 100 \\
& F_{2}=\left(\frac{\text { Number of failed tests }}{\text { Total number of tests }}\right) \times 100 \\
& F_{3}=\left(\frac{\text { nse }}{0.01 \text { nse }+0.01^{2}}\right) \\
& \text { excursion }_{i}=\left(\frac{\text { Failed tests Value }_{i}}{\text { objective }_{i}}\right)-1 \\
& \text { excursion }_{i}=\left(\frac{\text { objective }_{i}}{\text { Failed tests Value }_{i}}\right)-1 \\
& n s e=\frac{\sum_{i=1}^{n} \text { excursion }_{i}}{\# \text { of tests }^{-}} \\
& \text {CCME WQI }=100-\left(\frac{\sqrt{F_{1}+F_{2}+F_{3}}}{1.732}\right)
\end{aligned}
$$

\section{STORET Method}

STORET is a method of determining the status of water quality based on government regulations (KepMen LH RI No. 115/2003 on Guidelines for Determination of Water Quality Status) by comparing water quality parameter data with the water quality standard. Water quality parameters assessed include $\mathrm{DO}, \mathrm{BOD}, \mathrm{pH}$, temperature, Turbidity, TSS, Nitrate, Total phosphate, and Fecal Coliform in the period of 2005-2016. Calculation of STORET method using the following steps [8]: (1) Compare the value of the minimum, maximum, and average water quality data, (2) The result of water quality data complies with the water quality standard then given score 0 , (3) The result of water quality data does not comply with the water quality standard then given the score according to table 2, (4) All negative values are summed to get water quality status according to criteria.

Table 2. Parameter Value of Water Quality STORET [8].

\begin{tabular}{|c|l|c|c|c|}
\hline $\begin{array}{c}\text { Number of } \\
\text { Examples }\end{array}$ & Value & \multicolumn{3}{|c|}{ Parameters } \\
\cline { 2 - 5 } & & Chemistry & Physics & Microbiology \\
\hline \multirow{3}{*}{$<10$} & Maximum & -1 & -2 & -3 \\
\cline { 2 - 5 } & Minimum & -1 & -2 & -3 \\
\cline { 2 - 5 } & Average & -3 & -6 & -9 \\
\hline \multirow{3}{*}{$\geq 10$} & Maximum & -2 & -4 & -6 \\
\cline { 2 - 5 } & Minimum & -2 & -4 & -6 \\
\cline { 2 - 5 } & Average & -6 & -12 & -18 \\
\hline
\end{tabular}

\section{NSF-WQI Method}

The National Sanitation Foundation Water Quality Index (NSF-WQI) is one of the water quality analytical tools that commonly used to determined water quality status [9]. Calculation of NSF-WQI method using the following steps : (1) Determine the weight factor (Wi) and sub-index value ( $\mathrm{Li}$ ) for each parameter by using the sub-index function curve (Li). (2) Calculate the value of NSF-WQI using the following equation [9]:

$$
N S F \text { WQI }=\sum_{i=0}^{n} W i L i
$$

(3) NSF-WQI values are classified according to NSFWQI criteria. 


\subsection{Determination of Impervious Cover}

Impervious cover is any surface in the landscape that cannot effectively absorb or infiltrate rainfall [10]. These include residential roofs, roads, buildings, and the other impervious cover. In this study the impervious cover is defined as the Total Impervious Area (TIA) determined by BIG land use map 2009 [11] and the conversion of digital land use maps in 2006 and 2016 based on satellite imagery of google earth history. Total impervious area in each sub-watershed is obtained by using residential rooftops, building rooftops and transport systems as the component of impervious cover [9]. Land use data is processed using ArcGIS Software.

\subsection{Correlation and Regression}

Pearson correlation analysis is used to find the relationship between two variables, the impervious cover as the independent variable and the water quality indices as the dependent variables. The Kolmogorov-Smirnov normality test is used to determine whether the data distribution is normal or not. Regression analysis is used to determine the trend line of relationship between impervious cover and water quality indices. The change of impervious cover is analyzed to predict the change of water quality status due to impervious cover change.

\section{Result and Discussion}

\subsection{Impervious Cover Area}

Land use of Ciliwung watershed in 2006, 2009 and 2016 are processed using ArcGIS as shown as in Figure 4. Total impervious cover areas are calculated on each subwatershed cumulatively up to monitoring locations [9].

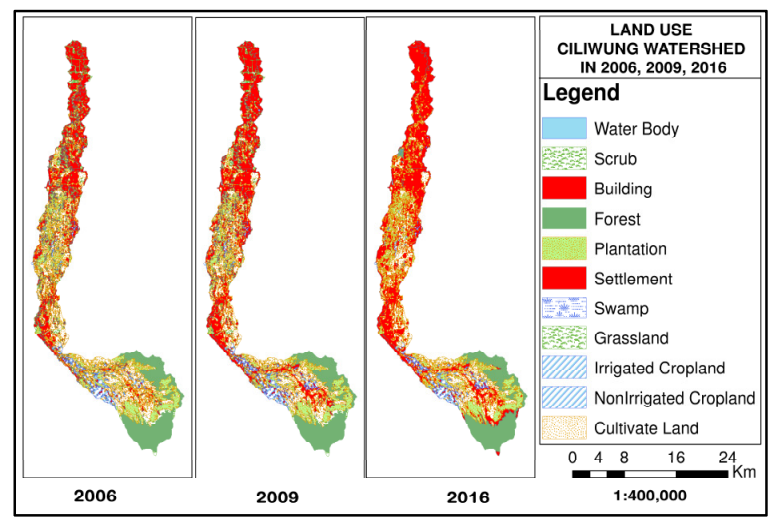

Fig. 4. Land Use Ciliwung Watershed

Figure 4 shows that impervious cover (residential rooftops, building rooftops and road) in Ciliwung watershed in 2006 to 2016 significantly increased from Atta'awun to Manggarai subwatershed. Percentage of impervious cover in Ciliwung watershed in 2016 includes Atta'awun 5\%, katulampa 17\%, Kedung Halang 21\%, Pondok Rajeg 28\%, Panus Bridge 30\%, Kelapa Dua 34\%, Condet $39 \%$, Kalibata $41 \%$, MT Haryono $42 \%$, and Manggarai $44 \%$. If calculated not cumulatively Kelapa Dua subwatershed up to Manggarai subwatershed have \% IC greater than $60 \%$. Impervious cover areas in other years (2005-2016) are obtained using linear regression based on the data 2006, 2009 and 2016 as shown as in Table 3.
Table 3. Total Area IC in Ciliwung Subwatershed

\begin{tabular}{|c|c|c|c|c|c|}
\hline \multirow{2}{*}{ SW } & \multicolumn{2}{|c|}{ Total Area IC $* \mathbf{K m}^{\mathbf{2}} \mathbf{2}$} & \multirow{2}{*}{ Trend Line $* *$} & \multirow{2}{*}{$\mathbf{R}^{\mathbf{2}}$} \\
\cline { 2 - 5 } & $\mathbf{2 0 0 6}$ & $\mathbf{2 0 0 9}$ & $\mathbf{2 0 1 6}$ & & \\
\hline 1 & 0.01 & 0.02 & 0.07 & $\mathrm{y}=0.57 \mathrm{x}-1135.10$ & 0.96 \\
\hline 2 & 12.48 & 19.73 & 26.12 & $\mathrm{y}=142.61 \mathrm{x}-284794$ & 0.94 \\
\hline 3 & 17.66 & 26.15 & 32.96 & $\mathrm{y}=159.98 \mathrm{x}-319107$ & 0.93 \\
\hline 4 & 34.84 & 47.30 & 60.88 & $\mathrm{y}=248.60 \mathrm{x}-495009$ & 0.96 \\
\hline 5 & 43.89 & 59.75 & 74.99 & $\mathrm{y}=294.45 \mathrm{x}-585989$ & 0.94 \\
\hline 6 & 59.26 & 77.06 & 93.87 & $\mathrm{y}=327.29 \mathrm{x}-650292$ & 0.94 \\
\hline 7 & 82.92 & 101.98 & 121.69 & $\mathrm{y}=368.87 \mathrm{x}-731323$ & 0.95 \\
\hline 8 & 93.00 & 112.37 & 132.67 & $\mathrm{y}=377.79 \mathrm{x}-748220$ & 0.95 \\
\hline 9 & 97.91 & 117.47 & 138.62 & $\mathrm{y}=388.45 \mathrm{x}-769114$ & 0.96 \\
\hline 10 & 109.32 & 129.13 & 151.12 & $\mathrm{y}=399.60 \mathrm{x}-790336$ & 0.96 \\
\hline
\end{tabular}

* SW = Ciliwung Subwatershed $* * \mathrm{y}=$ Total Area IC, $\mathrm{x}=$ years

Table 3 shows that Total Area IC in 2006 to 2016 significantly increased in each subwatershed (Atta'awun 4\%, Katulampa 9\%, Kedung Halang 10\%, Pondok Rajeg $12 \%$, Panus Bridge $12 \%$, Kelapa Dua 13\%, Condet $12 \%$, Kalibata 12\%, MT Haryono 12\%, and Manggarai 12\%). Total Area IC up to Manggarai subwatershed in 2006 to 2016 significantly increased from $32 \%$ to $44 \%$. Linear regressions value $\left(R^{2}>0.9\right)$ indicated that trend line can be used to estimate IC areas in other years.

\subsection{WQI Value}

Water quality indices (NSF-WQI, CCME-WQI and STORET methods) using Water quality parameters namely DO, BOD, pH, temperature, Turbidity, TSS, Nitrate, Total phosphate, and Fecal Coliform in the period of 2005-2016. The results of quantification of water quality indices in Ciliwung River and the impervious cover percentage from 2005 to 2016 are plotted to Impervious Cover Model (ICM) chart. ICM classification results from 2005 to 2016 are as follows: 1 Sensitive stream with less than 10\% IC (Attawun), 4 Impacted streams with 10-25\% IC (Katulampa, Kedung Halang, Pondok Rajeg, and Panus Bridge) and 4 Nonsupporting streams with $25-60 \%$ IC (Kelapa Dua, Condet, Kalibata Bridge, MT Haryono, and Manggarai).

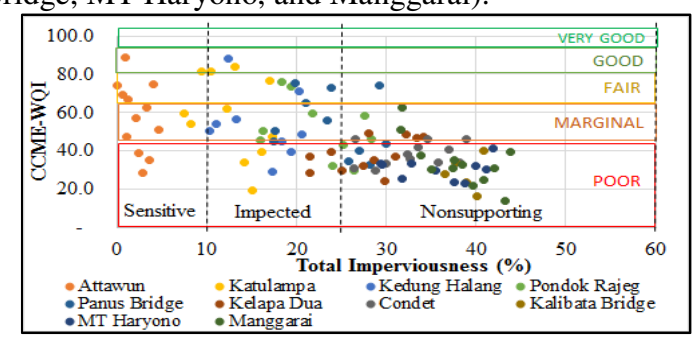

Fig. 5. Total Imperviousness vs CCME-WQI.

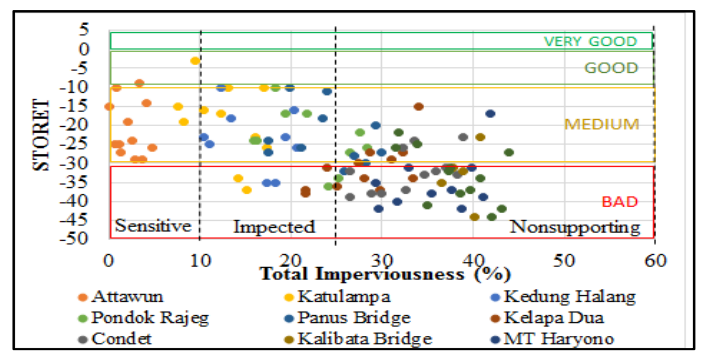

Fig. 6. Total Imperviousness vs STORET. 


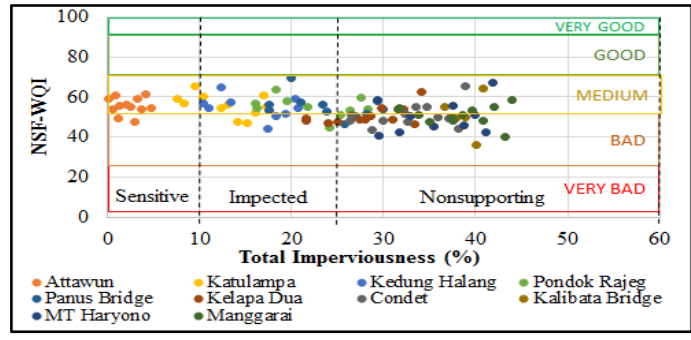

Fig. 7. Total Imperviousness vs NSF-WQI.

The ICM charts showed that the greater percentage of impervious cover, the water quality significantly decreased.

\subsection{Correlation and Regression Test}

The Kolmogorov-Smirnov normality and runs test showed that IC, NSF-WQI, CCME-WQI and STORET variables are normal distribution and not auto correlation with Asymptotic two-tailed significance/ $p$-value of each variable $>0.05$.

Table 4. Kolmogorov-Smirnov Normality and Runs Test

\begin{tabular}{|c|c|c|c|c|}
\hline & IC & $\begin{array}{c}\text { CCME- } \\
\text { WQI }\end{array}$ & STORET & $\begin{array}{c}\text { NSF- } \\
\text { WQI }\end{array}$ \\
\hline N & 104 & 104 & 104 & 104 \\
\hline Normality Sig. & 0.44 & 0.12 & 0.94 & 0.54 \\
\hline Runs Test Sig. & & 0.43 & 0.69 & 0.24 \\
\hline
\end{tabular}

The Pearson correlation analyses showed that impervious cover was significantly strong negative correlated with Water Quality Index CCME $(r=0.58, p$ $<0.01)$ and STORET $(r=0.54, p<0.01)$. While impervious cover was significantly negatively correlated with Water Quality Index NSF $(r=-0.32, p<0.01)$.

Table 5. Correlations \& Regression Test Results

\begin{tabular}{|l|r|r|r|}
\hline & CCME-WQI & \multicolumn{1}{|c|}{ STORET } & \multicolumn{1}{c|}{ NSF-WQI } \\
\hline Pearson $(\boldsymbol{r})$ & $-0.58^{* *}$ & $-0.54^{* *}$ & $-0.32^{* *}$ \\
\hline Sig. & 0.000 & 0.000 & 0.001 \\
\hline Regression & $-0.83 \times$ IC $(\%)+$ & $-0.53 \times$ IC $(\%)-$ & $-0.16 \times$ IC $(\%)+$ \\
WQI $=$ & $\begin{array}{c}65.52 ; \text { Sig. }=0.00 \\
\mathrm{R}^{2}=0.34\end{array}$ & $\begin{array}{c}14.07 ; \text { Sig. }=0.00 \\
\mathrm{R}^{2}=0.30\end{array}$ & $\begin{array}{c}56.93 ; \text { Sig. }=0.00 \\
\mathrm{R}^{2}=0.10\end{array}$ \\
\hline
\end{tabular}

** Correlation is significant at the 0.01 level (2-tailed).

The results of linear regression showed that Impervious cover significantly effecting Water Quality Index with CCME-WQI $\left(\mathrm{R}^{2}=0,34, p<0.01\right)$, STORET $\left(\mathrm{R}^{2}=0.30, p<0.01\right)$, and NSF-WQI $\left(\mathrm{R}^{2}=0.10, p<0.01\right)$, which means that the $\mathrm{R}^{2}$ values are variations of Impervious cover factor that can affect the water quality indices and the rest is influenced by other factors. Therefore, the linear regression model can be used to predict the change of water quality status in Ciliwung River in 2030.

Table 6. Results Predicted Water Quality Indices in 2030

\begin{tabular}{|c|c|c|c|r|c|r|c|}
\hline SW* & $\begin{array}{c}\text { \% } \\
\text { IC }\end{array}$ & $\begin{array}{c}\text { WS- } \\
\text { WQI }\end{array}$ & Status & $\begin{array}{c}\text { CCME } \\
\text {-WQI }\end{array}$ & Status & STORET & Status \\
\hline 1 & 10 & 55 & Medium & 57 & Marginal & -21 & Medium \\
\hline 2 & 31 & 52 & Medium & 39 & Poor & -30 & $\mathrm{Bad}$ \\
\hline 3 & 35 & 51 & Medium & 36 & Poor & -32 & $\mathrm{Bad}$ \\
\hline 4 & 45 & 50 & Medium & 28 & Poor & -36 & $\mathrm{Bad}$ \\
\hline 5 & 47 & 49 & Medium & 26 & Poor & -37 & $\mathrm{Bad}$ \\
\hline 6 & 51 & 49 & Bad & 23 & Poor & -38 & $\mathrm{Bad}$ \\
\hline
\end{tabular}

\begin{tabular}{|c|c|c|c|r|r|r|c|}
\hline SW* & $\begin{array}{c}\% \\
\text { IC }\end{array}$ & $\begin{array}{c}\text { NSF- } \\
\text { WQI }\end{array}$ & Status & $\begin{array}{c}\text { CCME } \\
\text {-WQI }\end{array}$ & Status & STORET & Status \\
\hline 7 & 56 & 48 & $\mathrm{Bad}$ & 19 & Poor & -40 & $\mathrm{Bad}$ \\
\hline 8 & 58 & 48 & $\mathrm{Bad}$ & 18 & Poor & -41 & $\mathrm{Bad}$ \\
\hline 9 & 59 & 47 & $\mathrm{Bad}$ & 17 & Poor & -41 & $\mathrm{Bad}$ \\
\hline 10 & 61 & 47 & $\mathrm{Bad}$ & 15 & Poor & -42 & $\mathrm{Bad}$ \\
\hline
\end{tabular}

* SW = Ciliwung Subwatershed

Overall predicted results in 2030 status of water quality in each subwatershed decreased, e.g. CCME-WQI in Katulampa and Kedung Halang decreased from "Marginal" to "Poor", NSF-WQI in Kelapa Dua decreased up to Manggarai from "Medium" to "Bad".

\section{Conclusion}

Impervious cover proved to have a strong inverse relationship with water quality indices. The results of the analysis show that Impervious cover factor can influence the water quality significantly and the rest is influenced by other factors. The correlation-regression models can be used to predict the water quality status of Ciliwung River. Therefore, the result can be a warning for all stakeholders that the management Ciliwung watershed is needed especially urban planning, monitoring and supervision to the waste management for residential, industrial and commercial areas in Ciliwung watershed.

\section{Acknowledgment}

The author would like to thank the financial support provided by Universitas Indonesia through the PITTA 2018 funding scheme under grant No.2422/UN2.R3.1/HKP.05.00/2018 managed by the Directorate for Research and Public Service and Special thanks to Evi Anggraheni and Environmental Agency Government DKI Jakarta and West Java Province.

\section{References}

[1] Kementerian Lingkungan Hidup RI, Status Lingkungan Hidup Indonesia 2012, (2012).

[2] R. Schiff and G. Benoit, J. Am. Water Resour. Assoc., 43, 712-730 (2007).

[3] Z. Liu, Y. Wang, Z. Li, and J. Peng, Environ. Earth Sci., 68, 2365-2373 (2013).

[4] J. B. Moring, U.S. Geol. Surv. Sci. Investig. Rep.,5101-C (2006).

[5] T. R. Schueler, L. Fraley-McNeal, and K. Cappiella, J. Hydrol. Eng., 14, 309-315 (2009).

[6] C. Bellucci, Proc. Water Environ. Fed., 1003-1018 (2007).

[7] Canadian Council of Ministers of the Environment, Canadian Water Quality Guidelines for the Protection of Aquatic Life: CCME Water Quality User's Manual Update 2017, (2017).

[8] Kementerian Lingkungan Hidup RI, KepMenLH RI No.115/2003 Tentang Pedoman Penentuan Status Mutu Air, (2003).

[9] D. Sutjiningsih, Impervious Cover and Stream Quality Prediction Based on Impervious Cover Model and Water Quality Index at Ciliwung River, West Java, (2016).

[10] T. Schueler, Cent. Watershed Prot. Ellicott City, MD, 1 (2003).

[11] BIG, Data Penggunaan Lahan Se-Jawa. Badan Informasi Geospasial, Cibinong Bogor, (2009). 